\title{
Prospects and Challenges in Creating Metro-Governments: The Case of Metro-Vigan Initiative in the Philippines
}

\author{
JACK B. ISOLANA, JD, DPA \\ Associate Professor V \\ Department of Political Science \\ College of Arts and Social Sciences \\ Mindanao State University-Iligan Institute of Technology \\ Iligan City, Philippines
}

Received: Oct. 31, $2020 \quad$ Accepted: Nov. , 2020 Online published: Dec. 3, 2020

doi:10.5296/jpag.v10i4.18031～URL: https://doi.org/10.5296/jpag.v10i4.18031

\begin{abstract}
Local problems that go beyond jurisdictional boundaries such as; traffic congestions, pollution, garbage collection and disposal, environmental degradation, flooding, criminalities, pandemic, and other public health issues are readily seen and felt in urban areas today. To effectively address these inter-local problems, the establishment of metropolitan organizations has become a necessity. One of the primary functions of metro government is to manage the affairs of urban growth particularly in addressing the problems that go beyond the geographical boundaries of local governments. As a developmental strategy among adjacent local government units, metropolization requires a rules-based approach in order to effectively govern and address inter-local government problems and concerns.

The common issues that metro governments deal with include urban growth areas development, controlling urban sprawl and its effects like pollution, solid waste disposal, traffic congestion and others. The rationale behind setting-up a single authority among local government units is to deal with inter-local concerns which cannot be efficiently and effectively addressed by disjointed actions of individual local government.

The study looked into the state of inter-local relations among the eight component-local government units of the Metro Vigan Coordinating Council (MVCC). It identifies the common problems that transcend the geographical boundaries of the local government units
\end{abstract}


as well as the common development potentials that can be optimized through inter-local cooperation. It highlighted the legal, institutional, and financial challenges of the Metro-Vigan initiative, and offers recommendation to deepen and broaden the inter-local cooperation.

Keywords: Metro Governments, Metro Vigan Coordinating Council (MVCC), -Local Government Units (LGUs), Local Chief Executives (LCEs), MOA-Memorandum of Agreement, Alliance Champion

\section{Introduction}

The passage of Local Government Code of 1991 in the Philippines has substantially devolved huge responsibilities to local governments for the provision of basic services such as; health, social welfare, agriculture, environment, and to some extent, public works, tourism, communications, and education. But, after twenty-five years of implementation, still a large number of Local Government Units (LGUs) find it difficult to support the full cost of devolution despite the increased shares in the Internal Revenue Allotment (IRA) from 20 to 40 percent.

Aside from problems brought about by decentralization, LGUs have to face new issues and problems as a result of urban growth. The 1987 Philippine Constitution and the Local Government Code of 1991 have offered alternative mechanisms for service delivery among LGUs confronted with problems and issues that go beyond their political and geographical boundaries through inter-local cooperation. Both laws recognized the right and even the need of LGUs to group themselves together to form a cooperative undertaking and use such as a platform to organize, manage, and finance common programs and services that encompass the member LGUs. The Philippine Constitution specifically provides that "Local government units may group themselves, consolidate or coordinate their efforts, services, and resources for purposes commonly beneficial to them in accordance with law" (Section 13, 1987 Philippine Constitution). On the other hand, the Local Government Code of 1991 underscored that "Local government units may, through appropriate ordinances, group themselves, consolidate or coordinate their effort, services and resources for purposes commonly beneficial to them" (Section 33, The Philippine Local Government Code)

In the Philippines, the creation of inter-local cooperation as a viable option in addressing common problems, promoting economic development, service delivery, and environmental protection has given emphasis way back in the early 90s. The pressures of addressing inter-jurisdictional concerns and the pursuit of common developmental goals have prompted the creation of a number of metro areas in the Philippines. Some of these metro areas include Metro Manila, Metro Naga, Metro Cebu, Metro BLIST (formerly Baguio), Metro CAMADA (formerly Dagupan), Metro Iloilo, Metro Cagayan de Oro, Metro Davao and Metro Vigan with their own metro-wide governing councils.

Metropolization as a developmental strategy is a complex process of convergence among local government units in a spreading urban development. Thus, the creation of metro organization is important to manage the affairs of urbanization and that their establishment 
requires a rules-based approach to efficiently and effectively deal with inter-LGU concerns. To succeed, it is important that a set of policies as well as management structures be put in place. This will ensure the realization of the full potentials and sustainability of metropolization. Equally important are the identification of funding sources and the degree of cooperation among LGUs. Oftentimes, the existence of policy issues that transcend jurisdictional boundaries is what triggers the establishment of metropolitan governance.

Among the fundamental issues facing all metros around the world is the determination of the metro's boundaries especially in addressing issues and concerns that transcend political boundaries. It is observed that collaborative management is a multi-organizational arrangement which seeks to solve problems that cannot be solved by a single organization (Visser, 2004). Jurisdiction-based management combines a high degree of collaboration with the advancement by cities of their strategic interests in an environment of inter-jurisdictional interdependence. Hence, collaborative management is being seen as a major part of the public manager's responsibilities.

Since metropolization is synergistic in nature, it requires that LGUs must be ready to partially surrender their autonomy to a metropolitan body. This requires a new perspective among political leaders to balance the costs and benefits subsumed in a more collaborative approach to urban sprawl. Needless to say, if the cost is greater, there is always an option to turn their back to the task of metropolization. On the other hand, a potentially beneficial arrangement can further entice an LGU to join such endeavor.

Among the typical issues that metro government should deal with include urban growth areas development, controlling urban sprawl and its effects like pollution, solid waste disposal, traffic congestion, and others. This became the logic behind setting-up a single authority among LGUs to deal with inter-local concerns which cannot be efficiently and effectively solved by disjointed actions of individual LGU. Thus, coordination and not hierarchy is the ultimate objective of a metropolitan body. Since coordination requires pooling of both human and material resources, a participating LGU must be willing to share and shoulder additional responsibilities. It is not as easy as it seems since local chief executives have varying political platforms and development perspectives.

Urban growth has resulted in a number of problems and governance issues primarily because urban sprawl transcends territorial boundaries. Urban sprawl follows a ribbon development along major transportation corridors which transcends jurisdictions (Laquian, 1995). Hence, there are a number of reasons to claim that the rise of metropolitan organizations in managing the affairs of urban areas has become a necessity.

The rationale of metropolitan organization hinges on the externality or fiscal equivalence principle. This principle pertains to the benefits derived by citizens on local services that are supposedly self-contained as they are paid by the citizens who use them. However, because of urbanization, there is a leakage of local services provided by local government that are consumed by outsiders (Sharpe, 1995).

Sharpe further observed that the most obvious problem is that a metro will always tend to be 


\section{Macrothink}

squeezed between two probably hostile forces - above a senior government apprehensive about a potential rival and below the traditional system of local government which for various reasons will be resentful of an interloper that will limit its authority. The upper problem may be all the more intense when the metropolitan area is the capital city.

\section{The Research Methodology}

To determine the prospects and challenges in creating Metro Vigan, an examination was made on the initiatives particularly the activities conducted and the processes being followed in the formation of the Metro Vigan. The study also looked into the existing inter-local relations between and among local government units of Metro Vigan using the theoretical framework of metropolization and fundamental requirements of metropolis. The data were gathered through interviews with local chief executives, administrators, and other concerned local officials, actual observation of the geographical location of the local government units, and analysis of pertinent documents and records.

In looking into the state of inter-local relations, the study identified and examined the problems in establishing the metro organization, the common problems transcending the geographical boundaries of the component-LGUs and the common development potentials that can be optimized through inter-local cooperation. It highlighted the legal, institutional, and financial challenges to the Metro Vigan initiative. At the end, the study offered recommendations to deepen and broaden inter-local cooperation in Metro Vigan.



Figure1. Map of Metro Vigan 


\subsection{The Study Sites}

These competing demands are apparent in the proposed Metro Vigan Coordinating Council or MVCC. After several years of lobbying and advocating for its implementation, its proponents have realized that there are indeed no short-cuts to achieving such ambitious goal. However, the laborious efforts of its initiators have not gone to naught. Through the years, the initiative has been spiralling and more support has been thrown out. In fact, a legislative proposal in Congress was submitted to institutionalize the MVCC through an act of congress during the $15^{\text {th }}$ Congress of the Philippine Congress.

No doubt that the MVCC serves as a crucial development strategy for the province of Ilocos Sur. The identified areas of cooperation among participating LGUs are crucial to the social, political, and economic progress of Metro Vigan. The potential areas of cooperation include: trade and industry, governance, infrastructure, environment, peace and order and public safety, tourism, agriculture, and social services such as health, education, transportation, communication and public utilities, and sports and youth development. Given this wide array of cooperation, the desire to operationalize the MVCC necessitates not only an internal consultation but external assessment as well. Internally, the key personalities in the proposed MVCC have already conducted a number of consultative meetings among the stakeholders not only to check on the viability of the plan but to lobby for its adoption as well. With the exception of one LGU in the past, there was a consensus among local government units comprising the MVCC to establish and join a metro body. A Memorandum of Agreement (MOA) among the LGUs comprising the MVCC has been inked after a series of consultations. Also, seven LGUs have already signed the memorandum of agreement (MOA) creating the MVCC. However, the adoption of MOA is only the first step of the entire process of metropolization.

Vigan Developing Council was formed by seven LGUs composed of one city and six municipalities, namely; Vigan City, Sta. Catalina, San Vicente, Caoayan, Bantay, San Ildefonso, and Santa. In formalizing the creation of the MVCC, the seven Local Chief Executives of the seven LGUs signed the memorandum of agreement creating the MVCC on September 8, 2008 and the individual LGU's Sangguniang Bayan and Panglungsod adopted the MOA through separate resolutions. Following the 2010 local elections which effected a change in local leadership, the Sangguniang Bayan of San Ildefonso, the supposedly eight members of the MVCC, passed a resolution signifying the municipality's interest to join the MVCC.

\section{The Findings}

Based on the examinations conducted, it was shown that there are significant deficiencies in the plan of MVCC. Among them, is the lack of clear organizational structure that is supposedly filled-up by competent and qualified personnel to carry out the cooperation. There was no Manual of Operation for the MVCC that would provide member-LGUs clear norms and guidelines in formulating and implementing policy decisions. Above all, an alliance champion was absent in the MVCC who supposedly served as the moral compass in uniting the member-LGUs towards the realization of their individual and collective goals. 
More importantly, there are no clear guidelines on the computation of annual monetary contributions among member LGUs. Financial matters are sensitive topic for discussion but failure of the MVCC members to clarify and resolve the issues affect the interest and willingness of the members to provide the annual contribution and in turn affect the implementation of metro-wide services. The lack of clear guidelines in the computation of the annual financial contribution emanates from the lack of the computation of the actual cost of operation and financing of development projects. Hence, MVCC will solely rely on external funding support.

In spite of these, MVCC has remained a logical step to address urban sprawl in the province. It was noted that the ratification of the MOA by individual legislative councils is important as it provides legal framework for its operation. With the concurrence of the individual Sanggunian, local chief executives can go full blast in performing their assigned roles in the MVCC without the apprehension that they may be sued for it, authorize the release of their LGUs' financial contribution in support of the different activities of the MVCC, delegate and even hire personnel for the operation of the MVCC, and start identifying, organizing, and implementing the metro-wide services that they identified as necessary in the MOA.

Corollary to the foregoing, there is also a need for the Executive Council to convene in order to activate and set the MVCC in motion. The Executive Council can also review and prioritize areas of cooperation among member LGUs. In setting the priorities for implementation, the MVCC will be able to realize short-term gains which can serve as incentives for pursuing the cooperation but without necessarily losing focus on long-term benefits that are likewise important to the sustainability of the cooperation. Part of this is the actual formulation of a strategic plan for the MVCC to set the vision, mission, and strategies to realize the development vision within a given period of time. The setting-up and activation of the organizational structure for implementation should also follow.

\subsection{The Metro Vigan Coordinating Council}

In 2008, the Metro Vigan initiative was seen to wane after the anticipated external support from Congress became uncertain. Despite this setback, the MVCC could still have continue to operate and succeed had the member-LGUs themselves remain committed to fulfil the provisions of the MOA, the internal initiatives, and resources to pursue the goals and aspirations of the MVCC. Furthermore, the MVCC can look for best practices in other metropolitan bodies in the country and borrow appropriate tools and mechanisms to manage and sustain metro area governance. In the end, the proponents of the MVCC are facing an encouraging scenario, that while other urban growth areas in the country are contemplating on the potentials of a metropolis, Metro Vigan is halfway through this initiative.

As a key convergence strategy for social, political, and economic progress among eight LGUs in Ilocos Sur, the MVCC has the potential to accelerate sustainable development and strengthen people empowerment in the region.

The MVCC has identified the areas of cooperation as shown in the table below: 
Table 1. Areas of Cooperation of MVCC

\begin{tabular}{|c|c|c|}
\hline No. & $\begin{array}{l}\text { Program/ } \\
\text { Project }\end{array}$ & Activities \\
\hline 1 & $\begin{array}{l}\text { public safety \& } \\
\text { order }\end{array}$ & $\begin{array}{l}\text { - } \text { peace and order } \\
\text { - fire safety } \\
\text { - disaster preparedness during typhoons and other } \\
\text { calamities }\end{array}$ \\
\hline 2 & $\begin{array}{l}\text { waste } \\
\text { management }\end{array}$ & $\begin{array}{l}\text { - garbage disposal } \\
\text { - waste segregation }\end{array}$ \\
\hline 3 & $\begin{array}{l}\text { environmental } \\
\text { protection }\end{array}$ & $\begin{array}{l}\text { - cleaning/dredging of rivers } \\
\text { - coastal management } \\
\text { - air pollution management }\end{array}$ \\
\hline 4 & $\begin{array}{l}\text { transportation } \\
\text { \&communication }\end{array}$ & $\begin{array}{l}\text { - traffic management } \\
\text { - public transport } \\
\text { - access to information }\end{array}$ \\
\hline 5 & $\begin{array}{l}\text { heritage } \\
\text { conservation, } \\
\text { trade \& tourism }\end{array}$ & $\begin{array}{l}\text { - community-based rural tourism (CBRT) } \\
\text { - protection/ promotion of traditional industries } \\
\text { - cultural mapping }\end{array}$ \\
\hline
\end{tabular}

Source of Data: PowerPoint presentation of Vigan City Councillor Franz Ranches (Ranches)

\subsection{Nominal to Inter-Local Cooperation}

For a couple of months after signing the MOA, the participating mayors and some designated representatives met several times to discuss the plans to operationalize the possible areas for cooperation. However, when the planned contribution from the participating LGUs as well as the anticipated external funding assistance did not materialize, the level of interest waned. The anticipated funding assistance supposedly would come from the following: General Appropriations Act (GAA) if the proposed bill of Representative Singson was approved, Office of the President if the President issued an Executive Order, and Provincial Government had the Governor issued an Executive Order.

Notwithstanding the presence of a MOA which spells out the rationale for the creation of the MVCC, areas for cooperation, organizational or administrative structure, and indicative financial arrangement, the level of inter-local cooperation is nominal to non-existent. The MVCC has not set up an office, appointed or designated the officials and staff who will manage the operation of the MVCC, formulated the organizational systems and procedures in the formulation and implementation of policy decisions and strategies, approaches, and agreement on the annual contribution and mobilize external sources of funds. 


\section{Macrothink}

Table 2. Metro Vigan Common Problems

\begin{tabular}{|c|c|c|c|c|c|c|c|c|c|c|c|c|c|c|}
\hline \multirow{2}{*}{$\begin{array}{c}\text { Metro Vigan } \\
\text { Component LGUs }\end{array}$} & \multicolumn{13}{|c|}{ Common Problems Based on Interviews } & \multirow{2}{*}{$\begin{array}{c}\text { Common } \\
\text { Problems } \\
\text { As } \\
\text { Identified } \\
\text { By } \\
\text { Proposed } \\
\text { House Bill No. } \\
2\end{array}$} \\
\hline &  & 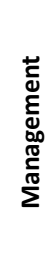 & 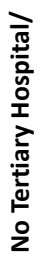 & 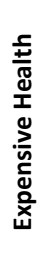 & $\frac{\mathscr{U}}{\sum}$ & $\begin{array}{l}\stackrel{\infty}{5} \\
\stackrel{5}{0} \\
\stackrel{0}{\circ} \\
\frac{0}{4}\end{array}$ & 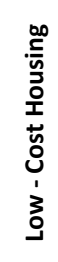 & 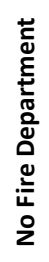 & 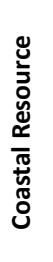 & 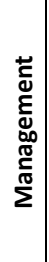 & 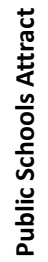 &  &  & \\
\hline 1. Bantay & & $x$ & & $\mathrm{x}$ & & $\mathrm{X}$ & & & & & & & & 1.Waste and \\
\hline 2. Caoayan & & $x$ & & & & $x$ & & & & & & & & Sewerage \\
\hline 3. San Ildefonso & & & & & & $x$ & & & & & & & & Management \\
\hline 4. San Vicente & & $\mathrm{x}$ & & $x$ & & & $x$ & $x$ & & & & & & 2. Health \\
\hline 5. Santa & & $x$ & & & & & & & & & & & & \\
\hline 6. Santa Catalina & & $x$ & & $x$ & & $x$ & & & $x$ & & & & & Planning and \\
\hline 7. Santo Domingo & & $x$ & & $\mathrm{x}$ & & & & & & & & & & Shelter \\
\hline 8. Vigan City & & $x$ & & & & & $\mathrm{X}$ & & & & & $x$ & $x$ & \\
\hline No. of Responses & & 7 & & 4 & & 4 & 2 & 1 & 1 & & & 1 & 1 & $\begin{array}{l}\text { 5.Public Safety } \\
\text { 6. Traffic }\end{array}$ \\
\hline
\end{tabular}

\subsection{Common Problems Affecting Component LGUs}

A series of interview with the municipal mayors, vice mayors and selected department heads revealed that the lack of systematic solid waste management program is a common problem affecting them all. They mentioned that Vigan City owns a bioreactor facility which can convert non-biodegradable waste into useful materials like chairs and tables but remains largely underutilized. By coming up with an agreement, they believed that they can use the said bioreactor facility and in turn keep their LGUs clean and provide livelihood to their constituents. The other two problems that affect four of the component LGUs are lack of tertiary hospital facility and flooding. The poor access to tertiary hospitals has forced patients from the municipalities of Bantay, San Vicente, Santa Catalina, and Santo Domingo to seek medical care in Vigan City. The costs of transport, food and other miscellaneous expenses have put a strain on their already limited budget.

Flooding is one of the local problems that does not respect geographical boundaries. Among the municipalities directly affected by flood namely; Bantay, Caoayan, San Ildefonso, and Santa Catalina, none of them can ever put up adequate infrastructures to spare them from the havoc of flooding.

\subsection{Absence of an Alliance Champion}

The presence of an alliance champion especially at the beginning of the cooperation cannot be overemphasized. An alliance champion is someone who can get the stakeholders together, 
initiate discussions regarding the formation of the alliance, see through the process until the alliance is organized and gets the alliance going especially through its initial stages (GTZ, 2010). In the case of the MVCC, they had two alliance champions but both did not last long enough to develop and nurture the MVCC into a viable and effectively functioning cooperation before they left.

The first alliance champion was former Vigan City Vice-Mayor and Councilor Franz Ranches who promoted the concept of MVCC among the component LGUs. He succeeded in bringing the mayors together and agreed to cooperation. The second alliance champion was former Congressman Ronald Singson but his unexpected resignation from the $15^{\text {th }}$ Congress had halted all efforts and motivation to push through with the cooperation via the passage of the proposed Metro Vigan heritage Development Authority. In the absence of an alliance champion, no one is motivating and at the same time persuading the component LGUs that cooperation is a viable option in addressing inter-jurisdictional problems and concerns as well as in promoting inter-jurisdictional opportunities.

\subsection{Nominal Involvement of Local Chief Executives}

After signing the MOA, it seems that Local Chief Executives of component LGUs failed to sustain the interest on cooperation. They have not taken concrete steps to implement the provisions of the MOA including the adoption of relevant policies, creation of a fully functioning organizational bureaucracy, and agreement on individual financial contribution. They have not reached agreements on other important concerns like the code of conduct during meetings, penalties for non-compliance of agreements and even procedures dropping and withdrawal of members. At most, the current involvement of the LCEs in the cooperation remains nominal. They are aware of the cooperation, remain supportive of it, but they are not doing concrete steps to make it work.

\subsection{Lack of Organizational Structure to Implement the Cooperation}

A clear organizational structure manned by competent and qualified personnel is necessary in implementing the cooperation. The provisions of the MOA concerning the creation of an organizational structure, the officers and staff needed to manage the cooperation, their functions and terms of office have remained on paper. The member LGUs have not fleshed out the guidelines in creating the structure, designating existing personnel or recruiting new ones to manage the cooperation.

\subsection{Lack of Manual of Operation}

The absence of a Manual of Operation is a logical consequence of lack of a functionally operating MVCC structure. The Manual of Operation will provide the member-LGUs clear norms and guidelines in formulating and implementing policy decisions affecting the cooperation. Unless amended in part or in whole and duly approved by the member LGUs, it remains in force thus lending the MVCC the necessary stability even throughout changes in local leadership. In its absence, the member-LGUs may be vulnerable to arbitrary, confusing and conflicting decisions that may seriously undermine the continued operation of the MVCC. Without it, each new set of officials especially at the beginning of their term will be 
experiencing some sort of difficulty, uncertainty or doubts which may lead to delays of existing projects, modification or discontinuation of planned projects to the detriment of target beneficiaries or LGUs.

\subsection{Lack of Clear Guidelines on the Computation of Annual Contribution}

While the MOA has provided that the component LGU will decide on the amount of annual contribution, the municipalities of Santa Catalina and San Ildefonso have claimed that the annual contribution is PhP50,000. It was not clear how the amount of PhP50,000 was reached. The issues often asked were: (1) Is the contribution uniform across all members regardless of differences in the levels of annual income and anticipated benefits? (2) Will the annual contribution vary depending on the capacity to pay of members and potential level of benefits they may receive? The determination of the amount of annual contribution per LGU is always tricky and the lack of clear guidelines may trigger other crucial issues, such as; annual contribution is not commensurate to anticipated benefits, tendency to free ride by some LGUs, capacity to pay by member LGUs has not been properly considered, and that rich LGU's may end up subsidizing poor LGUs.

\subsection{Reliance on External Funding Support}

The continued reliance of member-LGUs on external funding support has prevented them from looking inward among themselves on how best to finance the cost of operation of the MVCC. With the proposed bill creating MVCC being temporarily shelved due to the unexpected resignation of the proponent, former Congressman Ronald Singson and the anticipated financial assistance not pushing through as a consequence, initial efforts to implement the cooperation were momentarily halted. Just to emphasize how much the component-LGUs are anticipating external funding assistance to finance the cooperation, they lobby Governor Luis Singson to issue an Executive Order to support the alliance. The issuance of an Executive Order will provide assurance of regular funding support from the provincial government.

\subsection{Potential Areas of Cooperation in the MVCC}

The problems discussed above can be taken as an opportunity to explore inter-local cooperation as an option to address them. The inter-jurisdictional nature of the problems requires that concerned LGUs must strengthen their inter-local cooperation through the availability of resources, be it technical expertise, equipment or facilities, and financial contribution. Based on the interviews, the component-LGUs were interested to seek inter-local cooperation in three areas, namely; tourism development, inter-local health zone and solid waste management as shown in Table 3. 


\section{Macrothink}

Table 3. Potential Areas of Cooperation in the MVCC

\begin{tabular}{|c|c|c|c|c|c|c|c|c|c|c|c|c|c|c|c|c|}
\hline \multirow{2}{*}{$\begin{array}{c}\text { Metro } \\
\text { Vigan } \\
\text { Component } \\
\text { LGUs }\end{array}$} & \multicolumn{9}{|c|}{$\begin{array}{l}\text { Potential Areas of Cooperation Based on } \\
\text { Interviews }\end{array}$} & \multicolumn{7}{|c|}{ Areas of Cooperation as Indicated in the MOA } \\
\hline & 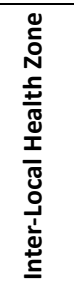 & 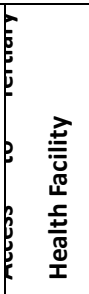 & 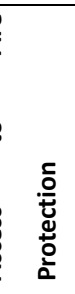 &  & 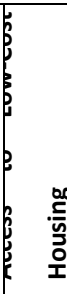 & & 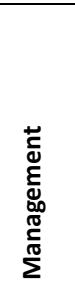 & 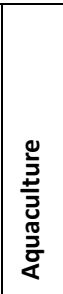 & 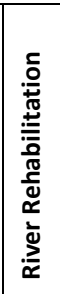 & 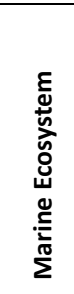 & $\begin{array}{l}\text { 龸 } \\
\text { : }\end{array}$ & 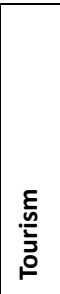 & 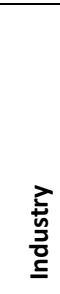 & 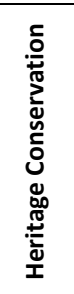 & 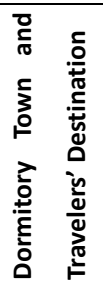 & \\
\hline Bantay & $x$ & & & $\mathrm{x}$ & & & & & & & & $\mathrm{x}$ & & & & - Waste \\
\hline Caoayan & & & & & & & $x$ & & & & & $x$ & $x$ & & & - Public Safety and \\
\hline $\begin{array}{l}\text { San } \\
\text { Ildefonso }\end{array}$ & & & & & & & & & & & & $\mathrm{x}$ & & & & $\begin{array}{l}\text { Order } \\
\text { - Environmental } \\
\text { Protection }\end{array}$ \\
\hline $\begin{array}{l}\text { San } \\
\text { Vicente }\end{array}$ & $\mathrm{x}$ & $\mathrm{x}$ & $\mathrm{x}$ & & $x$ & & & & & & & $\mathrm{x}$ & & & & $\begin{array}{l}\text { - Transportation } \\
\text { and } \\
\text { Communication }\end{array}$ \\
\hline Santa & & & & & & & & & & & & $x$ & & & & - Heritage \\
\hline $\begin{array}{l}\text { Santa } \\
\text { Catalina }\end{array}$ & $x$ & $x$ & & & & & & & & & $x$ & $x$ & & $x$ & $x$ & $\begin{array}{l}\text { Trade and } \\
\text { Tourism }\end{array}$ \\
\hline $\begin{array}{l}\text { Santo } \\
\text { Domingo }\end{array}$ & & & & & & & & $x$ & & & & $\mathrm{x}$ & & & & \\
\hline $\begin{array}{l}\text { Vigan } \\
\text { City }\end{array}$ & & & & & & & $x$ & & $x$ & $x$ & & $x$ & & & & \\
\hline $\begin{array}{l}\text { Number of } \\
\text { Responses }\end{array}$ & 3 & 2 & 1 & 1 & 1 & & 2 & 1 & 1 & 1 & 1 & 8 & 1 & 1 & 1 & \\
\hline
\end{tabular}

\subsection{Inter-Local Tourism Development and Management}

Tourism development and promotion was enthusiastically endorsed by all respondents as one area which they can explore and work on through the MVCC. A booming tourism industry opens up opportunities for business and investments in trade and industry, services, banking, transport, food, among others which in turn provides income and employment to local residents such as what being shown in Table 4. Consequently, these will address one of the common problems and inscribed in the World Heritage List of Sites and Monuments of the United Nations Educational, Scientific and Cultural Organization (UNESCO) in 1999. Vigan City has been attracting the biggest number of tourists. The respondents of other MVCC municipalities are optimistic that they will benefit from spill-over in Vigan City. They 
anticipated that the huge influx of tourists cannot all be accommodated in Vigan City thus they are preparing to provide alternative food and board services.

Yet, aside from food and board, each of these municipalities possesses attractive centuries-old edifices and distinct cultural traditions that were a legacy of the long colonial history it shared with Vigan City as well as beautiful natural land formations. Some of these attractions include the striking-neo-gothic inspired St. Augustine Church in Bantay and other similar churches in Caoayan, San Vicente and Santa Catalina; Palacio del Governador, former vacation house of the Spanish Governor in San Vicente; bell tower in Bantay and Sto. Domingo; watch tower in Santa. They also boast of natural attractions such as Mt. Tupir in Bantay; rivers in Caoayan, San Ildefonso, Santa and Santa Catalina, and beaches and bay walks in Santa, Santa Catalina and Sto. Domingo. The municipal government of Caoayan, for instance, is considering to propose a riverboat ride tour package that connects the municipality to Vigan City and Santa Catalina. To boost the tourism potential of the municipality, it also planned to establish the Pandan Port Development Zone which will house a boat terminal, market for fresh produce, eating facilities including floating restaurants, and souvenir shops. Each town celebrates its own fiesta and San Ildefonso commemorates the Basi Revolt every September which can certainly provide additional attraction and excitement in tour packages.

Table 4. Metro- Vigan Tourist Destinations, Distinct Cultural Traditions, and Indigenous Industries

\begin{tabular}{|c|c|c|c|c|}
\hline No. & $\begin{array}{l}\text { Local } \\
\text { Government } \\
\text { Unit }\end{array}$ & Tourist Spots/ Destinations & $\begin{array}{l}\text { Distinct Cultural } \\
\text { Traditions }\end{array}$ & $\begin{array}{c}\text { Indigenous/ Traditional } \\
\text { Industries }\end{array}$ \\
\hline 1 & Bantay & $\begin{array}{l}\text { - St. Augustine Church } \\
\text { - Bell Tower } \\
\text { - Quirino Bridge } \\
\text { - Victoria Park } \\
\text { - Mt. Tupir } \\
\text { - Diego Silang Park }\end{array}$ & - fiesta & $\begin{array}{l}\text { - bagnet (deep fried pork) } \\
\text { - ladek (pork residue) } \\
\text { - royal bibingka } \\
\text { - bamboo craft making }\end{array}$ \\
\hline 2 & Caoayan & $\begin{array}{l}\text { - River Cruise } \\
\text { - Pandan Port } \\
\text { - old church }\end{array}$ & - fiesta & $\begin{array}{l}\text { - Abel lloko making (loom } \\
\text { weaving) }\end{array}$ \\
\hline 3 & San Ildefonso & $\begin{array}{l}\text { - Bantaoay River (site of Basi } \\
\text { Revolt) } \\
\text { - River Cruise }\end{array}$ & $\begin{array}{l}\text { - Basi Revolt } \\
\text { commemoration }\end{array}$ & - Basi making (Gongogong) \\
\hline 4 & San Vicente & $\begin{array}{l}\text { - Palacio del Governador } \\
\text { - Balde for indigo } \\
\text { fermentation } \\
\text { - Balde as deep wells } \\
\text { - first school } \\
\text { - church }\end{array}$ & - fiesta & $\begin{array}{l}\text { - making of indigo dye } \\
\text { known as Tayum } \\
\text { - Basi making }\end{array}$ \\
\hline 5 & Santa & - Banaoang watch tower & - fiesta & - bolo making \\
\hline
\end{tabular}




\begin{tabular}{|c|c|c|c|c|}
\hline & & $\begin{array}{l}\text { - Quirino Bridge } \\
\text { - Beaches } \\
\text { - sunset at the beach }\end{array}$ & & $\begin{array}{l}\text { - loom weaving } \\
\text { - bamboo craft }\end{array}$ \\
\hline 6 & Santa Catalina & $\begin{array}{l}\text { - River Cruise } \\
\text { - Centuries Old Church } \\
\text { - hotel in farms } \\
\text { - powder soft beaches }\end{array}$ & - comedia & - bamboo craft \\
\hline 7 & Sto. Domingo & $\begin{array}{l}\text { - Nature Trek } \\
\text { - bell tower } \\
\text { - beaches/bay walk/ parks }\end{array}$ & $\begin{array}{l}\text { - danon } \\
\text { - tagunawa or } \\
\text { bayanihan }\end{array}$ & $\begin{array}{l}\text { - Basi making } \\
\text { - ceramics } \\
\text { - red "vigan" tiles }\end{array}$ \\
\hline 8 & Vigan & $\begin{array}{l}\text { - Heritage Houses } \\
\text { - River Cruise }\end{array}$ & - Fiesta & $\begin{array}{l}\text { - Pagburnayan (earth jar } \\
\text { making) }\end{array}$ \\
\hline
\end{tabular}

\subsection{Inter-Local Health Service Delivery}

Public health service delivery is one of the most acknowledged basic services by the poor sector of society, and yet it remains costly undertaking at the local level. With all the devolved services under the Local Government Code, health service eat up a big chunk of the local budget especially in the operation and maintenance of district, provincial, and tertiary hospitals. Many of local government health care clinics and hospitals suffered from lack of financial resources to support the necessary supplies, medicines, equipment, and personnel. In situations like these, the normal recourse of residents within the province is to flock to the provincial hospital usually located in the provincial capital just to seek diagnosis and treatment of various diseases including those that should have been handled first by the municipal health clinics. Thus, resulting in overcrowding and straining of resources at the provincial hospital. The municipalities of San Vicente and Santa Catalina pointed out the lack of tertiary hospital in their own jurisdiction compelling their constituents to go to Vigan City to avail of tertiary health care services which proved to be costly especially for low-income families. On the other hand, the municipality of Bantay has facilities for new-born screening, treatment of sexually transmitted diseases, and management of dengue outbreaks which through a mutually agreed cooperative arrangement can be shared by the neighboring LGUs.

The MVCC offers an opportunity for cooperation in the area of health service delivery. It can adopt inter-local health zone mode of cooperation which the Department of Health has been supporting throughout the country. The inter-local cooperation in health will enable the component LGUs to map out their strengths or resource advantage in terms of the number and available expertise of their personnel, equipment and facilities needed for diagnosis, treatment and management of various diseases. On the other hand, it allows them to identify their resource inadequacies in terms of personnel, equipment, and facilities. Through the inter-local health zone, the participating LGUs can forge an agreement on planning, managing and monitoring the use of resources to improve access to health care services of their constituents.

\subsection{Inter-Local Solid Waste Management}

On solid waste management, the Vigan City has assigned a ten-hectare lot for the solid waste 
management project. The lot hosts a bioreactor which can convert biodegradable wastes to organic fertilizer as well as a facility that converts non-biodegradable materials to usable tables and chairs for the day care centers. However, these facilities are underutilized at present due to inadequate volume of both biodegradable and non-biodegradable wastes. Local Officials have expressed hope that through the MVCC, Vigan City and other component LGUs like Bantay and Caoayan will come to an agreement on the delivery of required volume of biodegradable and non-biodegradable wastes, payment schemes on the use of facilities, and marketing and sale of converted/recycled products to particular sectors. In addition, the city government is planning to produce electricity from a biomass plant fuelled by garbage. The cooperative arrangements on solid waste management will both address the need to keep their LGUs clean and provide livelihood to their constituents.

\subsection{Shared Historical Linkage}

The existing metro-wide cooperative arrangement being pursued by the component-LGUs through the MVCC is not altogether new but rather finds support through shared historical links. The local governments comprising Metro Vigan have long historical ties with each other due to their integrated socio-economic and political interests. Long before the Spanish conquerors came to Ilocos Region, Vigan, was a flourishing center of trade and commerce, exchanging goods and products with the inhabitants up north and even with the Chinese merchants owing to its strategic location at the delta of Abra River leading to South China Sea.

\subsection{Existing Economic Links}

Another factor that may lend support to the existence of MVCC is the component-LGUs' economic links with each other. The MVCC is basically an agricultural area with crops and vegetable production and fishery as the main sources of income and livelihood. The major products include rice, corn, root crops, vegetables, bangus and tilapia. Santa prides itself as the vegetable basket in Ilocos Sur while Vigan City is known for its longganisa and bagnet. Owing to its proximity to Vigan City, the municipality of Caoayan, touted as the provincial fish bowl, it provides regular supply of fresh fish like tilapia, gobi, and bangus. Being the most urban in the MVCC and center of trade and commerce, Vigan City serves as the major market of the different commodities produced in the other component LGUs of the MVCC.

\section{Recommendations}

The individual legislative councils of all participating LGUs must pass an individual resolution ratifying the MOA to signify each LGU's commitment to the agreements in the promotion of inter-local cooperation as specified in the MOA. Under the present Local Government Code, agreements between and among LGUs must have joint executive and legislative support to ensure that the terms of the agreement are realized and not derailed, and worse, remained unimplemented due to political bickering. With the concurrence of the individual local legislative bodies, the local chief executives can go full blast in performing their assigned roles in the MVCC with less apprehension of being sued under it. The local chief executives may immediately authorize the release of the LGUs' financial contributions 
in support to the different activities of the MVCC. They can also delegate and even hire personnel for the operation of the MVCC and start identifying, organizing, and implementing metro-wide services that they identified under their Memorandum of Agreement.

\subsection{Review of the Memorandum of Agreement (MOA)}

Once the MVCC is effectively functioning, the participating LGUs should set a periodic review of the MOA to reflect the necessary adjustments or modifications to the agreement arising from changes in the local conditions or circumstances. The periodic review is necessary to ensure that the MOA that spells out the terms of the agreement remains relevant to them. Keeping the MOA relevant and useful to the participating LGUs is a significant step in keeping the LGUs together.

The conduct of periodic review of the MOA has to be governed by certain procedures which the participating LGUs should establish and agree upon. They need to concur on the manner and frequency of periodic review. Some of the issues that may be considered during the periodic review include the range of inter-jurisdictional problems that will be continued on one hand, and terminated on the other hand, size of annual contribution, possibility of admitting new members, and even the continued operation or termination of the MVCC itself.

\subsection{Ratification of Executive Committee's Agreements by Individual Councils}

There is a need for the individual legislative councils of component LGUs to ratify the agreement and decisions of the Executive Committee to ensure that they enjoy joint executive and legislative support and hence increases the probability that they will be implemented successfully. With joint political support for inter-jurisdictional programs, decisions on issuance of necessary administrative order, mobilizing resources, assigning personnel, and networking with partners will be facilitated which in turn translates to their smooth implementation.

\subsection{Review and Prioritization of Areas of Cooperation by Executive Council}

One of the important components of the MOA that has to be reviewed is the areas of metro-wide cooperation. The MOA which specifies the areas of cooperation has not been implemented yet and by inference, none of the areas of cooperation has been implemented as well. The decision whether to adopt all or only part of them, or if new areas will be considered, lies with the Executive Committee. Moreover, after identifying and agreeing on the areas of cooperation, the Executive Committee has to select which of them will be prioritized in the short, medium, and long term based on certain criteria such as urgency, nature, and extent of effects of non-implementation of the areas of cooperation in the LGUs, availability of technical expertise and financial resources. In setting the priorities for implementation, the MVCC will be able to realize short-term gains which can serve as incentives for pursuing the cooperation but without necessarily losing focus on long-term benefits that are likewise important to the sustainability of the cooperation. 


\subsection{Formulation of Strategic Plan}

There is a need for the MVCC to formulate a strategic plan to set the vision, mission and strategies to realize the development vision within a given period of time. During their term of office, the Executive Committee members must establish a clear set of development directions and a roadmap to achieve them which can serve as a guide in adopting certain strategies and mobilizing resources within and outside the MVCC. The same strategic directions will be used as a measure of how far the MVCC achieved what it has set to do and what gaps remain to be accomplished. For the MVCC to continue operating, it is important for the member LGUs to realize the desired benefits, to experience that the MVCC is persistently working towards addressing inter-jurisdictional issues and concerns which otherwise individual LGUs cannot effectively fulfill.

With regard to the participants of the strategic planning exercises, the MVCC may consider inviting select representatives from the private sector, civil society organizations, and even from concerned agencies of government in order to solicit a wide-ranging perspective on the issues and concerns requiring inter-local cooperation. This will also generate a sense of ownership and support to the projects that may be eventually implemented.

\subsection{Setting-up and Activation of the Organizational Structure for Implementation}

The MVCC MOA has identified the organizational structure that will carry out the metro-wide decisions and agreements but the MVCC Executive Committee has yet to set it up and activate it. But before it can set up the organizational structure, the member LCEs have to establish agreements on personnel management and implementing structure. On personnel management, some of the issues that they may have to agree on are as follows:

a. Will the MVCC hire new personnel or be manned by personnel assigned to it by member LGUs?

b. If the member LGUs delegate personnel to the MVCC, who will exercise jurisdiction over them, the mother LGUs or MVCC?

c. What is the personnel size of the MVCC?

d. What are the position classifications and qualification standards of personnel?

e. What is the nature of appointment of personnel - permanent or co-terminus?

f. What are the salary scales and other fringe benefits of personnel?

g. What are the standards, conditions and requirements for performance evaluation, promotion, leave of absence, imposition of discipline, termination and retirement?

On the implementing structure, some of the issues that the members have to agree on are as follows:

a. What is the size of the MVCC including the technical and administrative support group of the Executive Committee and Technical Working Group?

b. How many personnel will be assigned in each division/unit of the MVCC?

c. What specific powers will be assigned to the MVCC, specifically to the Technical Working Group and to each division/unit under it?

d. How often will the Technical Working Group meet? 
e. What budgetary provisions will be provided to the MVCC including the Executive Committee and Technical Working Group?

f. What reporting systems the Executive Committee and Technical Working Group will follow?

\subsection{Formulation of a Manual of Operation}

There is a need for the MVCC to formulate a Manual of Operation to establish the basic norms, rules, guidelines, and requirements to be followed in the formulation of decisions on a wide array of issues and concerns related to the management of MVCC. The Manual of Operation promotes transparency and fairness in decision making and eliminates the exercise of discretion which can be cited as a ground for accusations of bias and partiality and in turn discourage the member LGUs to continue with the cooperation. The Manual of Operation can cover the same areas included in the MOA such as "administrative, finances, operations, personnel, property, miscellaneous (e.g., reporting system), joint agencies (e.g., for coordination), duration, termination and renewal" (Lawrence, 2007).

\subsection{Establishment of a Monitoring System}

Not all members will act in the same manner. Some LCEs will implement the decisions and agreement in their respective LGUs without much prodding from the members while others delay and even fail to fulfil their responsibilities despite repeated reminders. To ensure the compliance of members and at the same time check on the progress of implementation, the Executive Committee members must agree among themselves on the manner, frequency, and extent of monitoring system including the incentives for compliance and penalties for non-compliance. It is important for the members to realize that the agreements are being carried out across the metro area and that non-compliance by some members will be checked and dealt with accordingly. Allowing non-compliance to go on unchecked may discourage other members to fulfil their end of the agreement and may eventually lead to withdrawal from the cooperation.

\subsection{Determining the Financial Costs and Sources for Development Programs and Projects}

A significant part of the strategic plan of the MVCC is to determine the financing costs and sources of the development programs and projects. Will the MVCC support the development cost alone or in partnership with the provincial and national government agencies, foreign funding institutions, private sector and NGOs? Whatever strategies will be adopted, it is important for the MVCC to show real gains in the short, medium, and long terms in order to sustain the interest and support of the member LGUs.

\subsection{Commitment to Provide Financial Contribution}

The MVCC MOA signed in 2008 by member LGUs has specified that each member will provide an annual financial contribution to support the operations of the MVCC. However, the member LGU's has yet to come up with an acceptable formula on the financial contribution. Depending on the estimated cost of operation, the annual contribution of LGUs may be based on a flat rate. It may be equivalent to two percent (2\%) of each member-LGU's 
development fund as in the case of Metro Naga Development Council or based on graduated amount relative to the annual income of the member-LGU. This would mean that LGUs with higher income will share more than the low-income earner. The choice of a formula depends on the circumstances as may be defined by the MVCC and the willingness of the members to pay the agreed amount.

\subsection{Timely and Regular Collection of Committed Funds}

Besides agreeing to the formula for computation the individual share, the members must also adhere to timely and regular collection of committed funds so as not to disrupt the regular operations of MVCC. Regular and timely payment of individual share as well as penalties for delay and default must be part of the agreement of the members and strictly enforced to ensure the smooth relations among members and in turn the continued existence and sustainability of MVCC.

\subsection{Need for Sharing of other Monetary and Non-Monetary Resources}

Regular operation of the MVCC requires both monetary and non-monetary resources. The member LGUs can share non-monetary resources such as personnel, equipment, facilities, vehicles, real properties among others with the MVCC so that the latter can save on the cost of personal services and capital outlay. The sharing of non-monetary resources must also be part of the agreement and follow certain procedures and even standards to prevent a scenario where some members are bearing the bigger part of the burden while the others are free-riding. If the impression that the burden is not shared equally in a supposedly mutually beneficial inter-local cooperation persists, it would become an issue which may eventually affect the continued existence of the cooperation.

\section{Summary and Conclusion}

The interest and willingness to pursue the MVCC have seemed to wane after the anticipated external support from Congress and Office of the Governor fizzled out. Despite this setback, the MVCC can still continue to operate and succeed if the member LGUs themselves remain committed to fulfill the provisions of the MOA. Rather than relying on outside assistance, the member LGUs can turn inward relying on internal initiative and resources to pursue the goals and aspirations of the MVCC. Generally, external help occurs when the implementing institution, in this case, the MVCC, has proven within and outside the metro area its commitment and capability to exercise metro governance largely on their own efforts.

Strong reliance on external assistance has constrained any of the MVCC member LCEs to rise up to the challenge of acting as an alliance or inter-local champion who will coordinate and steer the collective efforts of the members to push the MVCC to take off. The absence of an alliance or inter-local champion especially during the initial and critical stages of development of the MVCC has significantly stalled the efforts to establish it as a well-functioning metropolitan body that will preside over inter-jurisdictional service delivery.

In most inter-local alliances, the presence of trigger issue(s) that transcend geographical boundaries and cannot be addressed effectively by disparate and individual action of affected 
LGUs serves as a compelling reason that leads them to band together to forge a joint, collective, and collaborative effort. The increasing threat or risk that inter-jurisdictional issues poses when left unchecked to life, property, community, and the environment provokes a sense of compulsion or urgency of action among the affected LGUs.

In the case of the MVCC, the compelling reason appears not so much as the presence of trigger issues but rather the anticipation of external support to the MVCC and mutually beneficial gains in the foreseeable future arising from collaborative undertaking. The nature and extent of problems affecting the member LGUs remain manageable at the individual level and do not urgently need a collective action. On other hand, what is apparent among the member LGUs is the presence of an opportunity to coalesce with each other in such areas as tourism, health, solid waste management, infrastructure, and indigenous crafts and industries in order to promote economic growth and development. They acknowledged their shared historical, cultural and economic links as a motivating factor in promoting inter-local cooperation.

However, unlike the presence of trigger issue(s), the anticipation of future benefits has not been high enough to provoke compulsion and urgency of action which may explain why until now the MVCC has largely been inactive and in-operational. Citing the oft-repeated reason of having limited resources which can hardly spare for the annual contribution, the member LGUs have all this time waited for external support to materialize before they will take the next steps towards establishing and strengthening the MVCC. By doing so, they have failed to appreciate that the longer they delay their cooperative efforts in making the MVCC functional, the farther they are in realizing the anticipated gains that the cooperation may bring. Until the member LGUs realize that the continued inactivity of the MVCC leads to continuing opportunity loss, they may not be motivated enough to pursue the implementation of MVCC seriously.

For a possible model on how to manage and sustain an inter-local cooperation or metro area governance, the MVCC can look at the examples and experiences of some successful inter-local alliances or metro areas such as the Metro Iloilo Guimaras Development Coalition (MIGDC) and MNDC. The MVCC mayors and other technical officials can visit these suggested areas and interview the concerned political leaders and technical staff, and examine relevant documents in order to determine that factors that promote successful and effective management of inter-local cooperation.

Ultimately, the MVCC component LGUs must decide whether to continue or discontinue the cooperation based on their assessment on the pros and cons of the cooperation. If by their assessment, the mutual benefits to be gained are higher than the shared costs, they will continue with the cooperation. If they do so, there is a lot work waiting to be done to make the cooperation functionally effective. If on the contrary, the shared costs are higher than the expected mutual gains, there is no point in continuing with the cooperation at all. 


\section{Acknowledges}

The author acknowledges the mentoring of Dr. Remigio Edgardo Ocenar and the PA 359 Class - Comparative Local Government Administration.

\section{Reference}

GTZ, European Union, CIDA, PDF. (2010). Critical Ingredients in Building and Sustaining Inter-Local Cooperation. Makati City.

Laquian, A. (1995). The Governance of Mega-Urban Regions.In: McGee, T. G. (Ed.). The Mega-Urban Regions of Southeast Asia. Vancouver: UBC Press, 1995.

Lawrence, David M. (2007). County and Municipal Government in North Carolina Article 10. Interlocal Cooperation, Regional Organization, and City-County Consolidation. Chapel Hill: University of Carolina, 4.

Philippine Constitution. (1987).

Philippine Local Government Code of 1991.

Sharpe, L. J. (Ed.). (1995). The government of world cities: the future of the metro model. Wiley-Blackwell.

Vigan City Councilor Frans Ranches, Power Point Presentation on MVCC Municipal Government of Bantay. PowerPoint Presentation on Dur-as Bantay, January 31, 2011.

Visser, J. A. (2004). The Collaborative Management of the Metropolis. Journal of Public Administration Research \& Theory, 14(2), 257-257. https://doi.org/10.1093/jopart/muh017

\section{Copyright Disclaimer}

Copyright for this article is retained by the author(s), with first publication rights granted to the journal.

This is an open-access article distributed under the terms and conditions of the Creative Commons Attribution license (http://creativecommons.org/licenses/by/4.0/). 